M.I. Vorozhbiian ${ }^{a}$, N.A. Moroz ${ }^{a}$, R.M. Vorozhbiyan ${ }^{b}$, E.A. Mykhailova ${ }^{c}$

\title{
EFFECT OF HYDRODYNAMIC CAVITATION ON THE ABSORPTION PROCESSES OCCURRING IN THE PRODUCTION OF NITRIC ACID
}

\author{
${ }^{a}$ Ukrainian State University of Railway Transport, Kharkiv \\ ' National Technical University «Kharkiv Polytechnic Institute», Kharkiv \\ c Simon Kuznets Kharkiv National University of Economics, Kharkiv
}

\begin{abstract}
The research data on the process of the formation of acid under the conditions of hydrodynamic cavitation are presented in the paper. A change in the absorption properties of activated water exposed to the hydrodynamic cavitation has been established. The physicochemical characteristics of activated water, in particular electrical conductivity, $\mathrm{pH}$ value and redox potential, have been studied. It was confirmed that cavitated water can be used in technological processes during $10-15$ hours before returning its properties to the initial values. A positive effect of the cavitation on the adsorption capacity of liquid phase in the production of weak nitric acid was established. The use of the cavitation results in an increase in the conversion rate of nitrose gases by $20-30 \%$. The most significant effect is observed in the region of increased concentrations of nitric acid solutions supplied to the absorption column and at increased linear velocities of gaseous phase. The fullscale testing of the cavitated water used for the absorption division of the production of weak nitric acid showed a positive effect which had been revealed during experimental investigations.
\end{abstract}

Keywords: weak nitric acid, absorption, process, nitrogen oxides, hydrodynamic cavitation.

DOI: $10.32434 / 0321-4095-2019-123-2-87-92$

\section{Introduction}

Cavitation has a wide field of application in different technological processes which is determined by energy concentration in space and time that occurs during the collapse of a cavitation bubble in a liquid phase $[1,2]$. Commonly, cavitation is used in aqueous solutions. At the present time, there is no generalized theory of the water structure and properties. Water belongs to the liquids with abnormal properties that differ from those consisting of monoatomic or multiatomic spherical symmetric molecules. Water is decomposed when exposed to the hydrodynamic cavitation (mechanolysis). Alongside with the emission of excess energy, an excited water molecule is dissociated following the following mechanism:

$$
\begin{aligned}
& \mathrm{H}_{2} \mathrm{O} \leftrightarrow \mathrm{H}^{+}+\mathrm{OH}^{-} \\
& \mathrm{OH}^{-}+\mathrm{OH}^{-} \rightarrow \mathrm{H}_{2} \mathrm{O}_{2} \\
& \mathrm{OH}^{-}+\mathrm{H}_{2} \mathrm{O}_{2} \rightarrow \mathrm{HO}_{2}^{3-}+\mathrm{H}_{2} \mathrm{O}
\end{aligned}
$$

$$
\mathrm{OH}^{-}+\mathrm{HO}_{2}^{3-} \rightarrow \mathrm{H}_{2} \mathrm{O}+\mathrm{O}_{2}
$$

Due to the water mechanolysis the cavitation action results in an increased $\mathrm{O}_{2}$ concentration in the liquid phase. A change in the water structure with the formation of free hydrogen bonds provides its increased chemical reactivity.

The action of cavitation on water and water solutions leads to the phenomenon of mechanothermolysis. This means that mechano-chemical reactions are initiated in water which results in the formation of $\mathrm{HO}_{2}^{3-}, \mathrm{O}_{2}, \mathrm{H}_{2} \mathrm{O}_{2}, \mathrm{OH}^{-}$, and new hydrogen bonds are formed. Such action of cavitation on water changes its physicochemical properties, in particular $\mathrm{pH}$ value, electrical conductivity, surface tension, an increase in the number of free ions and active radicals, and the molecule restructuring and activation [3].

The authors of work [4] showed that the process of acid formation can be intensified by using hydrodynamic cavitation effect. This is of interest for the improvement and intensification of processes 
in different branches of industry including the production of weak nitric acid.

The purpose of the present research was to improve the technologies used for the conversion of nitrose gases into nitric acid on the basis of the analysis of the mechanisms of processes occurring in the liquid phase under the action of cavitation.

Within the framework of this research, we formulated the following problems: developing and designing the cavitator construction; estimating the emergence of fully-developed cavitation using different methods; defining the physicochemical properties of water solutions after the hydrodynamic cavitation; investigating the acid-formation process in the cavitation mode; investigating the absorption processes of activated water exposed to the hydrodynamic cavitation; detecting the mechanism of interaction of activated liquid phase with nitrogen oxides; and evaluating the obtained data in industrial conditions.

\section{Experimental}

Cavitation occurs due to a local reduction of pressure in the liquid that can also proceed during the passage through a converging device. Such a device can be developed and designed taking into account the specific features of the process under consideration [5].

Based on the results of the investigations performed by different authors and computations of the optimal geometric parameters of throttling devices, we manufactured a throttling device that allows us to achieve the mode of fully-developed cavitation.

The cavitation number, $\mathrm{K}$, is used as a dimensionless parameter characterizing the cavitation. This index defines the cavitation intensity that provides a specific physical and chemical action on a liquid phase. The cavitation number can be varied depending on the cavitation intensity from the appearance of single cavitation caverns, i.e. the initial cavitation to their maximum number, i.e. the fully-developed cavitation.

Thus, to design the cavitator, we took the cavitation number equal to 0.15 . The input pressure did not exceed $2 \mathrm{MPa}$ and the supplied liquid rate was $2 \mathrm{~m}^{3} / \mathrm{h}$.

Physicochemical properties of liquid were analyzed before and after its passage through the cavitator. We analyzed the electroconductivity, $\mathrm{pH}$ value and redox potential. These indices were measured using the WATER TEST device.

\section{Results and discussion}

The electric conductivity of water is determined by the availability of hydroxyl ions $\mathrm{OH}^{-}$and hydroxonium ions $\mathrm{H}_{3} \mathrm{O}^{+}$. The latter is formed due to the hydration of the cation $\mathrm{H}^{+}$, present in the water after its dissociation following the reaction (1).

The values of electrical conductivity of «ordinary» water prior to its treatment can be varied in the range of $(90-105) \cdot 10^{-6} \mathrm{Ohm}^{-1} \cdot \mathrm{cm}^{-1}[6]$. The conductivity of water subjected to the cavitation treatment increases as shown in Fig. 1. Mainly, it happens via an increase in temperature.

The $\mathrm{pH}$ value of «ordinary» water is in the range of 7.5 to 7.7. A change in the $\mathrm{pH}$ of water after the cavitation treatment is shown in Fig. 2. An increase in the value of this index is determined by the attachment of oxygen ions to the hydroxonium ions which results in an increased concentration of hydroxyl ions.

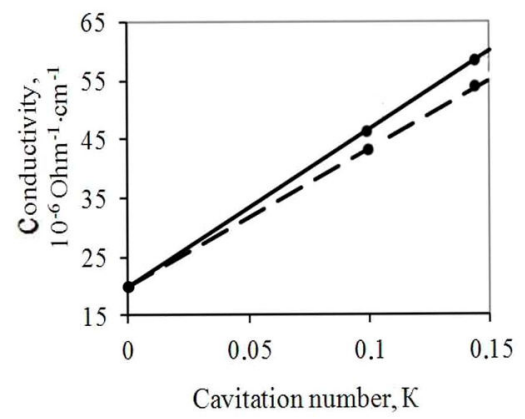

Fig. 1. Dependence of water conductivity on the cavitation number at the temperature of $283 \mathrm{~K}$ (dash line) and $298 \mathrm{~K}$ (solid line)

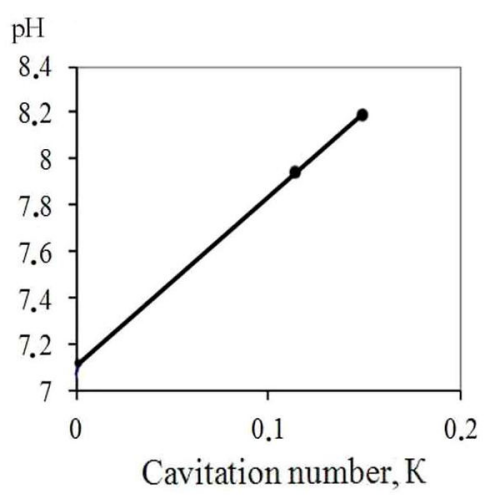

Fig. 2. Dependence of the $\mathrm{pH}$ value of water on the cavitation number

Fig. 3 shows the relationship between the redox potential of water $(\Delta \mathrm{E})$ subjected to the cavitation procedure and the cavitation number. It is seen that the redox potential diminishes with the cavitation number.

It is of interest to determine the retention period 
of the properties which have been acquired as a result of water activation. According to the data given in [7], it takes 30 hours to return the $\mathrm{pH}$ value of water to its stable state, 24 hours with regard to conductivity and about 48 hours with regard to $\Delta \mathrm{E}$ value.

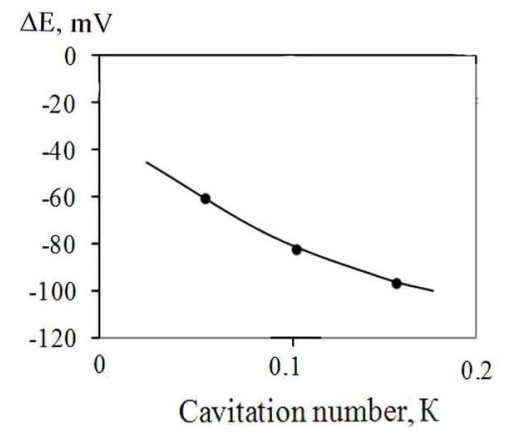

Fig. 3. Dependence of a change in the water redox potential on the cavitation number

A change of redox potential with time after the cavitation treatment is shown in Fig. 4. Thus, the conclusion is drawn that activated water can be used in technological processes during $10-15$ hours before its properties return to their initial values.

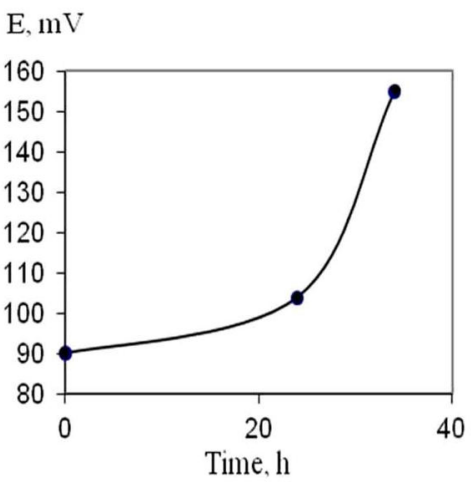

Fig. 4. Time dependence of a change in the redox potential

Taking into consideration the conditions that are created by fully-developed cavitation when the cavitation bubbles are collapsed, it assumed that a direct synthesis of nitric acid is quite possible. A laboratory plant of a circulation type was developed which consists of a cavitator and a vortex mixer and enables the generation of the nitrose gas and the water mixture in an appropriate proportion [8].

The reaction of $\mathrm{HNO}_{3}$ production requires a high pressure which can be provided via hydrodynamic cavitation. Nitrogen (II) oxide can be oxidized to nitrogen (IV) oxide in a liquid phase in the presence of oxygen. The liquid phase eliminates the gas-phase oxidation of $\mathrm{NO}$ to $\mathrm{NO}_{2}$.

Different ratios of gaseous and liquid phases supplied to the cavitator were selected and the initial concentration of $\mathrm{HNO}_{3}$ was equal to $30 \mathrm{wt} . \%$. The experimental data are given in Table. We failed to obtain a high conversion rate of $\mathrm{NO}_{x}$ into $\mathrm{HNO}_{3}$ and an increase in the concentration of nitric acid is insignificant.

The obtained data are indicative of the fact that nitric acid molecules are also activated, in addition to the water activation that results in the formation of ions. It is likely that the approximate balance is established between the partially destroyed acid molecules and the newly formed molecules with an insignificant advantage of the formation of nitric acid.

Further studies on the use of the cavitated water in the $\mathrm{NO}_{\mathrm{x}}$ absorption are of great interest, because the influence of activated water on the acid formation process can be determined. At this stage of our investigations, the essence of our experiments consists in the water preparation (i.e. cavitation) for its subsequent use for the spraying in the absorption column. The absorption column (one mass-exchange plate) had the following specifications: the diameter of $50 \mathrm{~mm}$, liquid phase overflow height of $100 \mathrm{~mm}$ and the free cross-section of the plate of $4 \%$ [9].

To define the effects of the hydrodynamic cavitation on the absorption properties of a liquid phase, all subsequent experimental investigations were carried out in two series: 1 - without a preliminary influence on the liquid phase; and 2 - with the

Experimental data on direct synthesis of $\mathrm{HNO}_{3}$ at different gas-to-liquid ratio

\begin{tabular}{|c|c|c|c|c|c|c|c|c|}
\hline \multicolumn{2}{|c|}{ Flow rate, $\mathrm{m}^{3} \mathrm{~h}^{-1}$} & \multirow{2}{*}{$\begin{array}{c}\text { Temperature of } \\
\mathrm{HNO}_{3} \text { solution, } \\
\mathrm{K}\end{array}$} & \multicolumn{3}{|c|}{ Pressure, $\mathrm{MPa}$} & \multicolumn{3}{|c|}{$\mathrm{HNO}_{3}$ concentration, wt. $\%$} \\
\hline $\begin{array}{c}\mathrm{HNO}_{3} \\
\text { solution } \\
\end{array}$ & $\mathrm{NO}_{\mathrm{x}}$ gas & & pump & in the mixer & $\begin{array}{c}\text { in the cavitator, } \\
1 \cdot 10^{-3}\end{array}$ & $\begin{array}{l}\text { before the } \\
\text { cavitator }\end{array}$ & $\begin{array}{l}\text { after the } \\
\text { cavitator }\end{array}$ & $\Delta$ \\
\hline 6.0 & 30.0 & 313 & 0.6 & 0.37 & -1.01 & 28.70 & 28.85 & 0.15 \\
\hline 6.0 & 30.0 & 300 & 0.6 & 0.37 & -1.52 & 29.55 & 29.70 & 0.15 \\
\hline 9.0 & 40.3 & 313 & 0.6 & 0.37 & -3.04 & 28.80 & 28.94 & 0.14 \\
\hline 10.5 & 50.0 & 310 & 0.6 & 0.37 & -4.05 & 29.99 & 30.15 & 0.16 \\
\hline 10.5 & 50.2 & 315 & 0.6 & 0.37 & -4.05 & 29.82 & 30.27 & 0.45 \\
\hline 14.0 & 70.0 & 312 & 0.6 & 0.37 & -4.56 & 29.82 & 30.14 & 0.32 \\
\hline
\end{tabular}


cavitation treatment of a liquid phase. The investigations were performed in the following ranges of process parameters: the pressure in the absorption column was atmospheric, the linear velocity of gas flow was $0.2-0.5 \mathrm{~m} / \mathrm{s}$, the concentration of the initial nitrose gas was $0.05-7.5 \mathrm{vol} . \%$, the concentration of acid supplied for the spraying was $0.9-45 \mathrm{wt} . \%$, and the temperature was $283-313 \mathrm{~K}$. Analytical control was conducted using standard techniques.

The influence of the cavitation on the absorption capacity of a liquid phase was established, since the conversion rate of $\mathrm{NO}_{\mathrm{x}}$ was increased by $20-30 \%$ under the conditions of the cavitation treatment. The most significant influence was observed in the region of higher concentrations of nitric acid solutions supplied to the absorption column and for the linear velocities of gaseous phase. Taking into consideration reactions $(1)-(4)$ considered earlier and as well as reactions (5) and (6):

$$
\begin{aligned}
& \mathrm{H}_{2} \mathrm{O}+\mathrm{O}_{2} \rightarrow \mathrm{H}_{2} \mathrm{O}_{2}+\mathrm{O}^{2-} ; \\
& \mathrm{O}^{2-}+2 \mathrm{H}^{+} \rightarrow \mathrm{H}_{2} \mathrm{O},
\end{aligned}
$$

the mechanism of acid formation with the use of activated water can be presented as follows:

$$
\begin{aligned}
& 2 \mathrm{NO}+\mathrm{O}_{2} \rightarrow 2 \mathrm{NO}_{2} ; \\
& \mathrm{NO}+\mathrm{H}_{2} \mathrm{O}_{2} \rightarrow \mathrm{NO}_{2}+\mathrm{H}_{2} \mathrm{O} ; \\
& \mathrm{HNO}_{2}+\mathrm{H}_{2} \mathrm{O}_{2} \rightarrow \mathrm{HNO}_{3}+\mathrm{H}_{2} \mathrm{O} .
\end{aligned}
$$

Using the method of mathematical statistics, the following equation was obtained:

$$
\mathrm{y}=\frac{1463 \cdot\left(1-\mathrm{C}_{\mathrm{HNO}_{3}}\right)^{0.5} \mathrm{C}_{\mathrm{NO}_{\mathrm{x}}}{ }^{0.4}}{\mathrm{w}^{0.2} \mathrm{~T}^{0.9}},
$$

where $\mathrm{y}$ is the treatment rate of nitrose gases (\%); $\mathrm{C}_{\mathrm{HNO}_{3}}$ is the concentration of nitric acid (unit fraction); $\mathrm{C}_{\mathrm{NO}_{\mathrm{x}}}$ is the concentration of nitrogen oxides (vol.\%); w is the linear gas velocity $(\mathrm{m} / \mathrm{s})$; and $\mathrm{T}$ is the temperature $(\mathrm{K})$.

Equation (10) allows calculating the conversion rate of nitrose gases into the nitric acid (the relative error is $7 \%$ ).

The empirical Equation (10) allowed evaluating both the influence of the absorption properties of water subjected to the cavitation treatment on the acid formation process and the possibility of its use for the calculation of acid formation processes in the absorption column supplied with the cavitated water for spraying.

The obtained experimental data were used for full-scale tests with the supply of cavitated water to the absorption column. An optimal ratio and the flow input point were established: $15 \%$ of the total amount of water for the 18th and 12th plates and $70 \%$ for the upper portion of absorption column. The cavitated water supplied to the absorption column affects the adsorption (Fig. 5). Indeed, a decrease in concentration of $\mathrm{NO}_{\mathrm{x}}$ is observed (15$20 \%$ ) at the absorption column output [10].

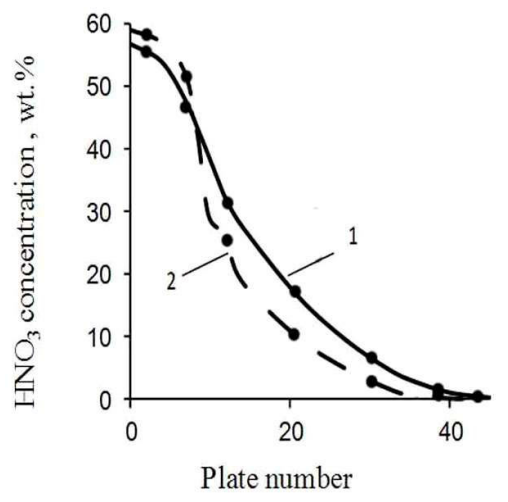

Fig. 5. Changes in the $\mathrm{HNO}_{3}$ concentration on the absorption column plates: (1) - standard operation of industrial absorption column; (2) - operation absorption column with the cavitated water delivery

\section{Conclusions}

1. The influence of the hydrodynamic cavitation on the absorption properties of water and the water solutions of nitric acid with regard to $\mathrm{NO}_{\mathrm{x}}$ conversion was theoretically and experimentally investigated.

2. The kinetic dependences of the process of acid formation in the following range of parameters: $\mathrm{HNO}_{3}$ concentrations of $0.9-45$ wt.\%; the linear velocity of $0.2-0.5 \mathrm{~m} / \mathrm{s}$; the concentrations of nitrogen oxides of $0.05-7.5$ vol. $\%$; and the temperatures of $283-313 \mathrm{~K}$. It was established that the conversion rate of nitrogen oxides into nitric acid increased by ca. $20 \%$ when the water was subjected to the cavitation treatment in comparison with the ordinary untreated water.

3. An equation was derived that allows calculating the treatment rate of nitrose gases.

4. Full-scale tests with the supply of cavitated water to the absorption column of the $\mathrm{HNO}_{3}$ production confirmed the positive effect of the water activation pretreatment. 


\section{REFERENCES}

1. Caupin F., Herbert E. Cavitation in water: a review // Comptes Rendus Physique. - 2006. - Vol.7. - No. 9-10. P.1000-1017.

2. Arrojo $S$., Benito $Y$. A theoretical study of hydrodynamic cavitation // Ultrasonics Sonochemistry. -2008. - Vol.15. No. 3. - P.203-211.

3. Viten'ko T.N., Gumnitskii Ya.M. A mechanism of the activating effect of hydrodynamic cavitation on water // Journal of Water Chemistry and Technology. 2007. - Vol.29. - No. 5. P.231-237.

4. Margulis M.A., Margulis I.M. Interaction of radial and forward pulses of cavitation bubbles // Proceedings of the 8th Conference of the European Society of Sonochemistry. - Italy. - 2002. - P.165.

5. Gogate P.R., Pandit A.B. A review and assessment of hydrodynamic cavitation as a technology for the future // Ultrasonics Sonochemistry. - 2005. Vol.12. - No. 1-2. - P.21-27.

6. Mishchenko K.P., Ravdel'A.A. Kratkii spravochnik fizikokhimicheskikh velichin. - Lenigrad: Khimiya, 1974. - 200 p.

7. Kulagin V.A. Metody i sredstva tekhnologicheskoi obrabotki mnogokomponentnykh sred s ispol'zovaniem effektov kavitatsii: Dissertatsiya ... d-ra tekhn. nauk: 01.04.14, 01.02.05. Krasnoyarsk: KGTU, 2004. - 406 p.

8. Izucheniye protsessa pogloshcheniya oksidov azota $\mathrm{v}$ rezhime kavitatsii / Moroz N.A., Kobzev A.V., Loboyko A.Y., et al. // Integrovani Tekhnologii i Energozberezhennya. - 2004. - No. 1. - P.82-84.

9. Vliyanie effekta kavitatsii na svoistva vodnykh rastvorov azotnoi kisloty / Vorozhbiian M.I., Moroz N.A., Loboyko A.Y., et al. // Visnik Natsional'nogo Tekhnichnogo Universytetu «KhPI». Zb. nauk. prats'. Tematychnyi vypusk «Khimiya, khimichna tekhnologiya i ekologiya». - 2007. - No. 32. - P.7-11.

10. $K$ voprosu o sovershenstvovanii tekhnologii proizvodstva azotnoi kisloty / Moroz N.A., Garmash B.K., Vorozhbiian M.I., et al. // Visnik Natsional'nogo Tekhnichnogo Universytetu «KhPI». Zb. nauk. prats'. Tematychnyi vypusk «Khimiya, khimichna tekhnologiya i ekologiya». - 2010. - No. 13. - P.52-58.

Received 12.11.2018

\section{ВПЛИВ ГІДРОДИНАМІЧНОЇ КАВІТАЦІЇ НА АБСОРБЦІЙНІ ПРОЦЕСИ В ТЕХНОЛОГІЇ ВИРОБНИЦТВА НІТРАТНОЇ КИСЛОТИ}

М.І. Ворожбіян, М.О. Мороз, Р.М. Ворожбіян, C.O. Михайлова

Наведено результати дослідження процесу кислотоутворення в режимі кавітації. Встановлено змінення абсорбційних властивостей активованої води, що було піддано гідродинамічній кавітації. Вивчено фізико-хімічні характеристики активованої води, а саме, електропровідність, водневий показник і окисно-відновний потенціал. Підтверджено можливість використання кавітованої води у технологічних процесах протягом 10-15 годин до повернення її властивостей до первинного стану. Встановлено позитивний вплив дії кавітації на абсорбційну здатність рідинної фази в технології неконцентрованої азотної кислоти. 3 використанням ефекту кавітаиія ступінь переробки нітрозних газів збільшуеться на 20-30\%. Найбільш істотний вплив спостерігається на ділянці більш високих концентрацій розчинів нітратної кислоти, що подаються в абсорбиійну колонну, і лінійних швидкостях газової фази. Промислові випробування щодо використання кавітованої води у відділенні абсорбиії виробництва неконцентрованої азотної кислоти, підтверджують позитивний ефект, який був встановлений в ході експериментальних досліджень.

Ключові слова: неконцентрована нітратна кислота, абсорбція, процес, оксиди нітрогену, гідродинамічна кавітація.

\section{EFFECT OF HYDRODYNAMIC CAVITATION ON THE ABSORPTION PROCESSES OCCURRING IN THE PRODUCTION OF NITRIC ACID}

M.I. Vorozhbiian ${ }^{a}$, N.A. Moroz ${ }^{a,}$ ", R.M. Vorozhbiyan ${ }^{b}$, E.A. Mykhailova ${ }^{c}$

a Ukrainian State University of Railway Transport, Kharkiv, Ukraine

b National Technical University «Kharkiv Polytechnic Institute», Kharkiv, Ukraine

c Simon Kuznets Kharkiv National University of Economics, Kharkiv, Ukraine

*e-mail: ssekret@ua.fm

The research data on the process of the formation of acid under the conditions of hydrodynamic cavitation are presented in the paper. A change in the absorption properties of activated water exposed to the hydrodynamic cavitation has been established. The exicochemical characteristics of activated water, in particular studied. It was confirmed that cavitated water can be used in technological processes during 10-15 hours before returning its properties to the initial values. A positive effect of the cavitation on the adsorption capacity of liquid phase in the production of weak nitric acid was established. The use of the cavitation results in an increase in the conversion rate of nitrose gases by 20-30\%. The most significant effect is observed in the region of increased concentrations of nitric acid solutions supplied to the absorption column and at increased linear velocities of gaseous phase. The full-scale testing of the cavitated water used for the absorption division of the production of weak nitric acid showed a positive effect which had been revealed during experimental investigations.

Keywords: weak nitric acid; absorption; process; nitrogen oxides; hydrodynamic cavitation. 


\section{REFERENCES}

1. Caupin F., Herbert E. Cavitation in water: a review. Comptes Rendus Physique, 2006, vol. 7, pp. 1000-1017.

2. Arrojo S., Benito Y. A theoretical study of hydrodynamic cavitation. Ultrasonics Sonochemistry, 2008, vol. 15, pp. 203-211.

3. Viten'ko T.N., Gumnitskii Ya.M. A mechanism of the activating effect of hydrodynamic cavitation on water. Journal of Water Chemistry and Technology, 2007, vol. 29, pp. 231-237.

4. Margulis M.A., Margulis I.M., Interaction of radial and forward pulses of cavitation bubbles. Proceedings of the 8th Conference of the European Society of Sonochemistry. Italy, 2002, p. 165 .

5. Gogate P.R., Pandit A.B. A review and assessment of hydrodynamic cavitation as a technology for the future. Ultrasonics Sonochemistry, 2005, vol. 12, pp. 21-27.

6. Mishchenko K.P., Ravdel' A.A., Kratkii spravochnik fiziko-khimicheskikh velichin [Short reference book of physicochemical values]. Khimiya, Leningrad, 1974. 200 p. (in Russian).

7. Kulagin V.A., Metody i sredstva tekhnologicheskoi obrabotki mnogokomponentnykh sred s ispol'zovaniem effektov kavitatsii [Methods and instruments of the technological treatment of multicomponent media using cavitation effects]: thesis for the degree of Doctor of Technical Sciences, Krasnoyarsk, 2004. 406 p. (in Russian).

8. Moroz N.A., Kobzev A.V., Loboyko A.Y., Bagdasarian V.S., Vorozhbiian M.I. Izuchenie protsessa pogloshcheniya oksidov azota v rezhime kavitatsii [Studying the nitrogen oxide absorption process in the cavitation mode]. Integrovani Tekhnologii i Energozberezhennya, 2004, no. 1, pp. 82-84. (in Russian).

9. Vorozhbiian M.I., Moroz N.A., Loboyko A.Y., Kobzev A.V., Markova N.B. Vliyanie effekta kavitatsii na svoistva vodnykh rastvorov azotnoi kisloty [Influence of the cavitation effect on the properties of aqueous solutions of nitric acid]. Bulletin of the National Technical University «KhPI», 2007, no. 32, pp. 7-11. (in Russian).

10. Moroz N.A., Garmash B.K., Vorozhbiian M.I., Loboyko A.Y, Markova N.B. K voprosu o sovershenstvovanii tekhnologii proizvodstva azotnoi kisloty [On the issue of improving the technology of nitric acid production]. Bulletin of the National Technical University «KhPI», 2010, no. 13, pp. 52-58. (in Russian). 